\title{
Insights from eight years of adoption experience of transcatheter mitral valve repair in Germany: observed utilisation patterns and impact on overall mitral valve procedure volumes
}

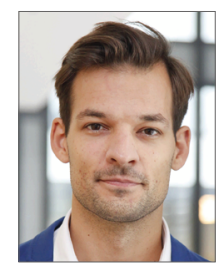

Andreas Schaefer ${ }^{*}$, MD, MHBA; Edith Lubos ${ }^{1}, \mathrm{MD}$; Jan Benjamin Pietzsch², PhD;

Malte Pietzsch ${ }^{3}, \mathrm{PhD}$; Simon Weber ${ }^{3}$; Stefan Blankenberg ${ }^{1}, \mathrm{MD}$;

Hermann Reichenspurner ${ }^{1}, \mathrm{MD}, \mathrm{PhD}$; Ulrich Schäfer ${ }^{1}$, MD; Lenard Conradi ${ }^{1}$, MD

1. University Heart Center Hamburg, Hamburg, Germany; 2. Wing Tech Inc., Menlo Park, CA, USA; 3. Wingtec GmbH,

Karlsruhe, Germany

This paper also includes supplementary data published online at: http://www.pcronline.com/eurointervention/142nd_issue/177



\section{Abstract}

Aims: The German healthcare system was among the first to introduce transcatheter mitral valve repair (TMVR) into routine care. The objective of this study was to analyse adoption and utilisation patterns and to estimate the impact of TMVR availability on mitral valve (MV) procedure volumes in the first eight years after commercialisation.

Methods and results: Procedure volumes were collected from German Federal Statistics Office databases for TMVR and mitral valve surgery (MVS) from 2008-2015. Procedure volumes were stratified by age group $(<65,65-74,75-84, \geq 85$ years). Overall procedure volumes grew from 14,525 to $24,898(+71 \%)$. MVS procedures grew from 14,477 to $20,402(+41 \%)(\mathrm{p}=0.008)$. The proportion of TMVR procedures grew from $0.3 \%$ ( 48 procedures) to $18.1 \%$ (4,496 procedures) $(\mathrm{p}=0.008)$. In 2015 , TMVR use reached $5 \%$, $15 \%, 31 \%$, and $68 \%$ of overall MV procedures in the studied age groups $(<65,65-74,75-84, \geq 85$ years $)$. MVS volumes grew in all age groups, with the highest increase in the age group $<65(+2,945)$.

Conclusions: The availability of TMVR has contributed to a pronounced increase in MV procedure volumes in Germany. Simultaneously, MVS procedure volumes continued to grow substantially. The highest increase of TMVR was observed in elderly populations, suggesting referral of patients with MV disease previously left untreated.

\footnotetext{
*Corresponding author: University Heart Center Hamburg, Martinistraße 52, 20246 Hamburg, Germany. 


\begin{tabular}{|c|c|}
\hline \multicolumn{2}{|c|}{ Abbreviations } \\
\hline COAPT & $\begin{array}{l}\text { Cardiovascular Outcomes Assessment of the } \\
\text { MitraClip Percutaneous Therapy }\end{array}$ \\
\hline DRG & diagnosis-related group \\
\hline EAC & early adopting centre \\
\hline EVEREST & Endovascular Valve Edge-to-Edge Repair Study \\
\hline GSTCVS & $\begin{array}{l}\text { German Society for Thoracic and Cardiovascular } \\
\text { Surgery }\end{array}$ \\
\hline ICD-10-GM & $\begin{array}{l}\text { International Statistical Classification of Diseases } \\
\text { and Related Health Problems, revision } 10, \\
\text { German modification }\end{array}$ \\
\hline ICPM & $\begin{array}{l}\text { International Classification of Procedures in } \\
\text { Medicine }\end{array}$ \\
\hline LV & left ventricle/ventricular \\
\hline MATTERHORN & $\begin{array}{l}\text { Multicenter, Randomized, Controlled Study } \\
\text { to Assess Mitral vAlve reconsTrucTion for } \\
\text { advancEd Insufficiency of Functional or iscHemic } \\
\text { ORigiN }\end{array}$ \\
\hline MC & MitraClip \\
\hline MR & mitral regurgitation \\
\hline MVS & mitral valve surgery \\
\hline NUB & $\begin{array}{l}\text { Neue Untersuchung- und Behandlungsmethoden } \\
\text { (new examination and treatment methods) }\end{array}$ \\
\hline OPS & $\begin{array}{l}\text { Operationen- und Prozedurenschlüssel (operation } \\
\text { and procedure code) }\end{array}$ \\
\hline TMVR & transcatheter mitral valve repair \\
\hline & transcatheter mitral valve interventions regist \\
\hline
\end{tabular}

\section{Introduction}

According to guideline-directed treatment schemes, severe symptomatic mitral regurgitation (MR) or asymptomatic chronic severe primary MR with left ventricular (LV) dysfunction or enlargement indicates mitral valve surgery (MVS) utilising repair or replacement. Also, concomitant MVS in patients with severe chronic primary MR or chronic moderate-severe secondary MR who undergo cardiac surgery for different indications is justified ${ }^{1}$. However, only $50 \%$ of patients suffering from relevant MR receive surgical treatment due to impaired LV ejection fraction, advanced age and/or relevant comorbid conditions with associated high surgical risk ${ }^{2}$. The clinical availability of transcatheter mitral valve repair (TMVR) has introduced new therapeutic options for high-risk patients formerly ineligible for causal treatment. Among the commercially available TMVR systems, most experience has been gathered with the MitraClip $^{\circledR}$ (MC) device (Abbott Vascular, Santa Clara, CA, USA) $)^{3,4}$.

The MC system was initially evaluated in the EVEREST I (Endovascular Valve Edge-to-Edge Repair Study) and EVEREST II trials, resulting in FDA approval for high-risk patients with degenerative MR ineligible for $\mathrm{MVS}^{5-7}$. Furthermore, the efficacy of the MC device is currently being evaluated against best medical therapy in the COAPT (Cardiovascular Outcomes Assessment of the MitraClip Percutaneous Therapy) randomised controlled trial $^{8}$ and against MVS in the MATTERHORN (Multicenter, Randomized, Controlled Study to Assess Mitral
vAlve reconsTrucTion for advancEd Insufficiency of Functional or iscHemic ORigiN) trial ${ }^{9}$. In Europe, TMVR using the MC system is predominantly used as an adjunctive heart failure therapy in inoperable patients with functional MR but is also approved for primary MR. In the USA, MC is only approved for primary $\mathrm{MR}$ in patients with severe symptoms who are at prohibitive risk for surgery ${ }^{10}$.

A previous study reported on the first years of experience with TMVR and concurrent development of surgical volumes at an early adopting centre (EAC) in Germany during the period 2008$2012^{11}$. The main finding of that study was that, concurrent to adoption of TMVR, MVS procedure volumes continued to exhibit meaningful growth.

The primary objective of the present study was to update these prior findings by extending the study time period to 2015, and to provide a more detailed evaluation of adoption patterns and growth trends in various age groups at the German national level. This extended analysis is of particular relevance as TMVR indications will probably continue to expand ${ }^{12}$, and Heart Teams evaluate their decision processes based on experience gained in earlier years. Furthermore, analysis of the more recent national data provides insight into TMVR adoption patterns observed with more widespread adoption of the therapy and additional initiation of TMVR programmes across the country. These data are of relevance beyond the German context, as similar patterns may emerge across other healthcare systems in Europe and North America.

\section{Methods \\ DATA COLLECTION}

MVS and TMVR procedure volumes were assessed for the period 2008 to 2015 at the German national level. Respective procedural volume data were collected for relevant mitral valve procedure codes and were collected from national records as previously described ${ }^{11}$ : relevant procedure codes (referred to as Operationen- und Prozedurencodes [OPS]; OPS codes represent the German national modification of the "International Classification of Procedures in Medicine" [ICPM]) were prospectively identified using the following approach (Supplementary Table 1 for OPS codes utilised):

- search annual OPS catalogues from 2008 until 2015 for codes containing the word "mitral"

- exclude all OPS codes containing the word "congenital"

- exclude OPS codes not relevant in the context of the current study (among them change of bioprosthetic or mechanical valves, treatment of mitral stenosis, thrombectomy)

Therapy- and age-stratified procedure volumes were collected from the German Federal Statistical Office for the years 20082015. Selected age groups were defined as follows: $<65,65-74$, $75-84$, and $\geq 85$ years.

To evaluate changes in reimbursement, diagnosis-related group (DRG) reimbursement amounts for the respective codes and years were collected from published records, using respective DRG base rates of the applicable federal state (Supplementary Appendix 1). 


\section{MORTALITY RATES}

Nationwide data regarding mortality are not documented at the German Federal Statistical Office. Therefore, in-hospital and 30-day mortality for the nationwide patient collective was implicitly acquired from already published data from the transcatheter mitral valve interventions (TRAMI) registry for MC therapy for the years 2010-2013 and the German Society for Thoracic and Cardiovascular Surgery (GSTCVS) for MVS for the years 2008-2015.

\section{STATISTICAL ANALYSIS}

Volumes were analysed annually for TMVR and MVS and stratified by age group. Growth rates were calculated on an annual basis, and for the specified analysis timeframe. All data are presented as absolute numbers and percentages for categorical variables. For statistical analyses of trends and differences in procedure volume growth rates - overall and by age group - a nonparametric test for trend across ordered groups (Cuzick's test, an extension of the Wilcoxon rank-sum test, with correction for ties) was utilised. Testing was performed for the TMVR group, the MVS group, and for the difference between these two groups. For all analyses, statistical significance was determined based on a p-level of 0.05 . All statistical analyses were performed using Stata 14 (StataCorp, College Station, TX, USA), and Excel 2013 (Microsoft Corporation, Redmond, WA, USA) software packages.

\section{Results}

\section{NATIONAL PROCEDURE VOLUMES}

In the study period, overall procedure volumes grew from 14,525 to $24,898(+71 \%)$. MVS procedure volumes grew from 14,477 to $20,402(+41 \%)$. TMVR procedures grew from 48 procedures in 2008 to 4,496 procedures in 2015. P for trend values were 0.008 for TMVR and for MVS, and 0.345 for the difference between the group growth rates, indicating statistically significant volume growth over time for both the TMVR and the MVS groups, but not for the difference between these two growth rates (Figure 1).

\section{RELATIVE PROPORTION OF TMVR PROCEDURES}

The proportion of TMVR procedures as part of the overall MV procedures grew from $0.3 \%$ (48 procedures) in 2008 to $18.1 \%$

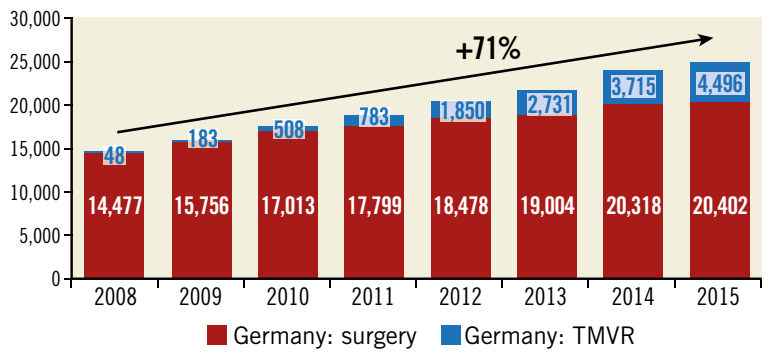

Figure 1. Total number of TMVR and surgical interventions at German national level, years 2008-2015.

(4,496 procedures) in 2015. TMVR proportions continued to exhibit year-on-year increase across the study horizon. Statistical testing found a $\mathrm{p}$ for trend value of 0.008 for Germany (Figure 2).

\section{PROCEDURE VOLUMES AND PROPORTIONS OF TMVR STRATIFIED BY AGE COHORT}

In 2015 , TMVR use reached $5 \%, 15 \%, 31 \%$, and $68 \%$ of overall MV procedures in the studied age groups $(<65,65-74,75-84$, $\geq 85$ years) (Figure 3 ). Compared to base year 2008, MVS volumes grew in all age groups over the eight-year study period, with the highest increase in the age group $<65(+2,945 ;+51.5 \%)$ and smallest increase in the age group $\geq 85$ years $(+85$ procedures; $+40.9 \%$ ) (Supplementary Figure 1 ).

Absolute procedural volumes exhibited a statistically significant growth trend over time for TMVR across all age groups in Germany ( $p$ for trend $=<65: 0.010 ; 65-74: 0.008 ; 75-84: 0.008 ; \geq 85: 0.008$ ). For MVS procedure volumes, positive $\mathrm{p}$ for trend values were observed in all age groups except for the age group $\geq 85$ years ( $p=<65$ : 0.008 ; 65-74: 0.012; 75-84: 0.008; $\geq 85$ : 0.231) (Supplementary Figure 2).

For growth in the relative proportion of TMVR of overall procedure volumes, a positive $\mathrm{p}$ for trend was observed for all age groups in Germany ( $\mathrm{p}$ for trend $=<65$ : $0.010 ; 65-74$ : $0.008 ; 75-84$ : $0.008 ; \geq 85: 0.008$ ).

\section{EVOLUTION OF REIMBURSEMENT}

The per-case reimbursement for TMVR increased from 28,400 euros in 2008 to 35,500 euros in $2015(+25 \%)$, attributable to gradual

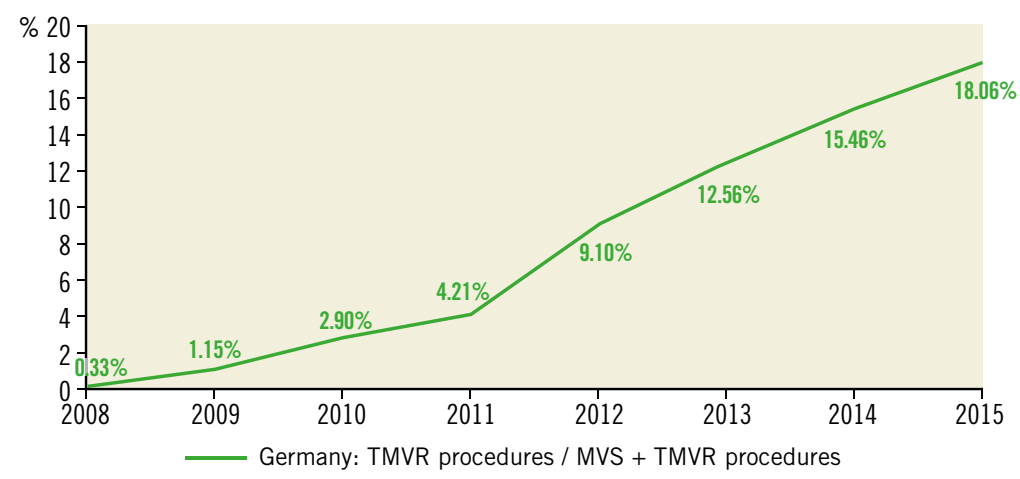

Figure 2. Percent of overall mitral valve procedures performed as TMVR at German national level, years 2008-2015. 


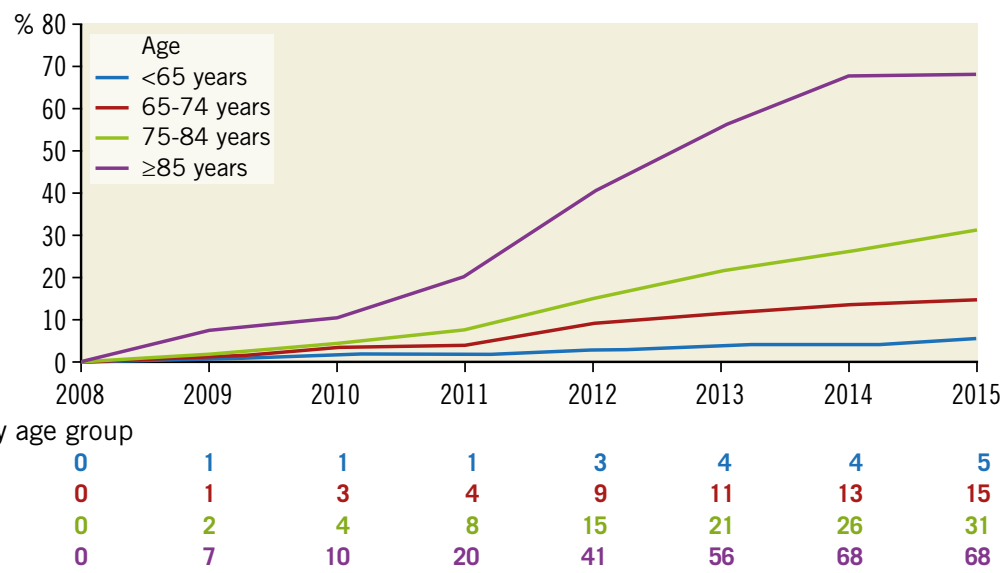

Figure 3. Percent of total mitral valve procedures performed as TMVR, by age group in Germany, years 2008-2015.

adjustments in the DRG reimbursement amounts for TMVR. Supplementary Figure 3 shows an example of reimbursement increase at a single centre.

\section{IN-HOSPITAL AND 30-DAY MORTALITY}

Isolated MVS in Germany presented an in-hospital mortality as documented annually by the GSTCVS: $4.9 \%$ in $2008,4.0 \%$ in $2009,4.0 \%$ in $2010,4.5 \%$ in $2011,4.1 \%$ in $2012,4.1 \%$ in 2013 , $4.1 \%$ in 2014 and $4.2 \%$ in $2015^{13-20}$. Available data from the TRAMI registry from 2010 to 2013 presented an in-hospital and 30 -day mortality for TMVR of $2.4 \%$ and $4.5 \%$, respectively ${ }^{21}$.

\section{Discussion}

The findings of this study provide new insight into diffusion and adoption patterns observed for TMVR in the German healthcare system, which was the first to adopt TMVR in 2008. The results suggest that TMVR has seen significant adoption over the last few years with the proportion of TMVR procedures approaching one fifth of overall mitral valve procedure volumes. The increasing proportion of TMVR in relation to all MV procedures is probably due to additional referral of patients with MV disease previously left untreated because of severely impaired LV ejection fraction, advanced age and/or relevant comorbid conditions with associated high surgical risk. Since the introduction of TMVR into clinical routine, these patients with functional or degenerative MR can now be provided with an adequate therapy. Additionally, awareness of novel TMVR therapies has increased over recent years, resulting in allocation of a high-risk patient population from cardiologists.

In parallel to TMVR, MVS procedure volumes have continued to grow substantially, further corroborating findings from an earlier study on TMVR adoption experience suggesting a "halo effect" of TMVR on MVS. This growth can be partially attributed to established mitral valve centres providing experienced Heart Teams who evaluate allocated patients in an unbiased fashion. Thereby, patients who were initially assigned for TMVR are regularly transferred to MVS and vice versa. This effect is confirmed by the herein described robust growth rates of MVS at the EAC. On the other hand, this growth may also be driven by effects such as the increase of prevalence in an ageing population, improved diagnostic tools and a more liberal indication and referral policy ${ }^{22}$.

Previously unreported adoption patterns by age group suggest that TMVR has experienced the most pronounced growth in elderly patients, which underlines the genuine patient population for which TMVR was approved in Europe, i.e., elderly patients with functional MR and an increased risk for MVS. This particular subgroup of patients was also largely dominant in a recently published TMVR registry ${ }^{23}$. Furthermore, TMVR is rarely utilised in younger patients and only when prohibitive surgical risk is present or for other rare indications such as for bridge to transplantation ${ }^{24}$.

Evaluating procedure volume evolution at our centre in detail, it was observed that TMVR volumes, after years of high growth rates, have exhibited slower growth rates in more recent years, more closely resembling the increase observed in MVS volumes. This effect is possibly explained by increasing availability of sites offering TMVR across the country, which reduces the potential number of referrals to the EAC. A second hypothesis is that patients who are candidates for TMVR are effectively identified by the Heart Team approach, and the relative proportion of TMVR remains stable at an experienced MV centre. Supplementary Figure 4-Supplementary Figure 6 show comparisons of nationwide and single-centre growth rates of TMVR and MVS.

At the national level, a significant increase in TMVR procedures in all age groups was documented by the analysis. Significance testing for trends showed statistically significant growth trends for both TMVR and MVS. In our centre, we saw a non-significant TMVR growth trend for the age group $\geq 85$ years over time which is largely due to an early steep uptake of TMVR procedures, and a more level volume development thereafter. Also, the diffusion of TMVR to surrounding centres may have contributed to this non-significance. 
MVS procedure volumes continued to grow in all studied age groups after the introduction of TMVR until 2012. From then on, the age group of patients $\geq 85$ years experienced a reduction in MVS volumes in Germany since TMVR experienced further growth in this population. At the same time, MVS procedure volumes saw the highest growth rates in patients $<65$ years of age, emphasising again the halo and crossover effect of a TMVR programme for MVS and overall mitral valve procedures.

Reimbursement analysis at our centre suggests continued increase in reimbursement revenues. While this increase is heavily driven by the adoption of TMVR, it is noteworthy that MVS procedure reimbursement concurrently more than doubled in the study period.

\section{Limitations}

The current analysis is subject to several limitations. First, it relies on volumes determined from procedure counts, as opposed to case counts. Changes in procedure coding and coding practices might have occurred over the study period and might also vary somewhat between individual hospitals. However, reliance on procedure codes provided a level of granularity in characterising the TMVR and MVS groups that would not have been possible by analysing DRG case volumes published by the national statistics office. Further, trends observed in procedure volumes can be expected also to reflect corresponding relative changes in overall case counts. Second, while our analysis considers volume development in different age groups, it does not consider other cohort characteristics and risk factors that would be of interest to study, and that might correlate with some of the observed volume changes. Third, volume developments in individual centres might be driven by a wide variety of factors. Finally, nationwide mortality rates were achieved implicitly and do not cover the whole timeframe investigated here. Therefore, there is a methodological inconsistency regarding comparison of TMVR and MVS mortality rates. Also, this work does not provide information about the clinical benefit of TMVR, the ideal patient population or optimal intervention timing for catheter-based mitral valve therapy.

\section{Conclusions}

In summary, our analysis suggests that the availability of TMVR has contributed to pronounced growth in overall MV procedure volumes in Germany. At the same time, MVS procedure volumes continued to grow substantially. The highest growth of TMVR was observed in elderly populations, suggesting referral of patients with MV disease previously left untreated. Halo and crossover effects contributed to a parallel increase in MVS procedures. This growth can be partially assigned to established mitral valve centres providing experienced Heart Teams who evaluate allocated patients in an unbiased fashion. Thereby, patients who were initially assigned for TMVR are regularly transferred to MVS and vice versa. A shift of intermediate-risk patients to a TMVR regimen, as observed in other transcatheter therapies for valvular heart disease ${ }^{25,26}$, seems unlikely; therefore, TMVR is an additional and not a competitive therapy for MVS.

\section{Impact on daily practice}

The introduction of TMVR into daily clinical routine led to a referral of patients with MV disease previously left untreated. Evaluation of these allocated patients in an unbiased fashion is of crucial importance to provide the best care for every patient Experienced Heart Teams should be a mandatory prerequisite for this assessment.

\section{Funding}

Wing Tech Inc. (J.B. Pietzsch, S. Weber, M. Pietzsch) provided health-economic consulting services to Abbott Vascular in support of this analysis and received compensation for its services. The authors maintained the right to publish without the approval of the funding source.

\section{Acknowledgements}

The authors thank Dr Benjamin Geisler (Wing Tech Inc.) for providing statistical analysis support.

\section{Conflict of interest statement}

A. Schaefer reports other from Abbott Vascular, outside the submitted work (travel support). J.B. Pietzsch reports other from Abbott Vascular, during the conduct of the study (compensation for healtheconomic consulting services). M. Pietzsch reports other from Abbott Vascular, during the conduct of the study (compensation for healtheconomic consulting services). S. Weber reports other from Abbott Vascular, during the conduct of the study (compensation for healtheconomic consulting services). L. Conradi reports other from Abbott Vascular, outside the submitted work (speaker honoraria, travel compensation). The other authors have no conflicts of interest to declare.

\section{References}

1. Nishimura RA, Otto CM, Bonow RO, Carabello BA, Erwin JP 3rd, Guyton RA, O'Gara PT, Ruiz CE, Skubas NJ, Sorajja P, Sundt TM 3rd, Thomas JD; ACC/AHA Task Force Members. 2014 AHA/ACC Guideline for the Management of Patients With Valvular Heart Disease: executive summary: a report of the American College of Cardiology/American Heart Association Task Force on Practice Guidelines. Circulation. 2014;129: 2440-92.

2. Mirabel M, Iung B, Baron G, Messika-Zeitoun D, Détaint D, Vanoverschelde JL, Butchart EG, Ravaud P, Vahanian A. What are the characteristics of patients with severe, symptomatic, mitral regurgitation who are denied surgery? Eur Heart J. 2007;28: 1358-65.

3. Glower DD, Kar S, Trento A, Lim DS, Bajwa T, Quesada R, Whitlow PL, Rinaldi MJ, Grayburn P, Mack MJ, Mauri L, McCarthy PM, Feldman T. Percutaneous mitral valve repair for mitral regurgitation in high-risk patients: results of the EVEREST II study. J Am Coll Cardiol. 2014;64:172-81.

4. Alfieri O, Maisano F, De Bonis M, Stefano PL, Torracca L, Oppizzi M, La Canna G. The double-orifice technique in mitral 
valve repair: a simple solution for complex problems. J Thorac Cardiovasc Surg. 2001;122:674-81.

5. Feldman T, Wasserman HS, Herrmann HC, Gray W, Block PC, Whitlow P, St Goar F, Rodriguez L, Silvestry F, Schwartz A, Sanborn TA, Condado JA, Foster E. Percutaneous mitral valve repair using the edge-to-edge technique: six-month results of the EVEREST Phase I Clinical Trial. J Am Coll Cardiol. 2005;46:2134-40.

6. Feldman T, Foster E, Glower DD, Kar S, Rinaldi MJ, Fail PS, Smalling RW, Siegel R, Rose GA, Engeron E, Loghin C, Trento A, Skipper ER, Fudge T, Letsou GV, Massaro JM, Mauri L; EVEREST II Investigators. Percutaneous repair or surgery for mitral regurgitation. N Engl J Med. 2011;364:1395-406.

7. Head SJ, van Leeuwen WJ, Van Mieghem NM, Kappetein AP. Surgical or transcatheter mitral valve intervention: complex disease requires complex decisions. EuroIntervention. 2014;9:1133-5.

8. Cardiovascular Outcomes Assessment of the MitraClip Percutaneous Therapy for Heart Failure Patients With Functional Mitral Regurgitation (The COAPT Trial) (COAPT). ClinicalTrials. gov Identifier: NCT01626079. http://clinicaltrials.gov/ct2/show/ NCT01626079.

9. https://clinicaltrials.gov/ct2/show/NCT02371512. Last accessed: 13 March 2017.

10. Nishimura RA, Vahanian A, Eleid MF, Mack MJ. Mitral valve disease--current management and future challenges. Lancet. 2016;387:1324-34.

11. Conradi L, Lubos E, Treede H, Pietzsch JB, Weber S, Pietzsch M, Overlack K, Diemert P, Blankenberg S, Reichenspurner H. Evolution of mitral valve procedural volumes in the advent of endovascular treatment options: Experience at an early-adopting center in Germany. Catheter Cardiovasc Interv. 2015;86:1114-9.

12. Marmagkiolis K, Cilingiroglu M. Time to Expand the MitraClip Indications. Catheter Cardiovasc Interv. 2015;86:736-7.

13. Gummert JF, Funkat A, Beckmann A, Schiller W, Hekmat K, Ernst M, Haverich A. Cardiac surgery in Germany during 2008. A report on behalf of the German Society for Thoracic and Cardiovascular Surgery. Thorac Cardiovasc Surg. 2009;57: 315-23.

14. Gummert JF, Funkat A, Beckmann A, Schiller W, Hekmat K, Ernst M, Beyersdorf F. Cardiac surgery in Germany during 2009. A report on behalf of the German Society for Thoracic and Cardiovascular Surgery. Thorac Cardiovasc Surg. 2010;58:379-86.

15. Gummert JF, Funkat AK, Beckmann A, Ernst M, Hekmat K, Beyersdorf F, Schiller W. Cardiac surgery in Germany during 2010: a report on behalf of the German Society for Thoracic and Cardiovascular Surgery. Thorac Cardiovasc Surg. 2011;59: 259-67.

16. Funkat AK, Beckmann A, Lewandowski J, Frie M, Schiller W, Ernst M, Hekmat K, Gummert JF, Mohr FW. Cardiac surgery in Germany during 2011: a report on behalf of the German Society for Thoracic and Cardiovascular Surgery. Thorac Cardiovasc Surg. 2012;60:371-82.
17. Beckmann A, Funkat AK, Lewandowski J, Frie M, Schiller W, Hekmat K, Gummert JF, Mohr FW. Cardiac surgery in Germany during 2012: a report on behalf of the German Society for Thoracic and Cardiovascular Surgery. Thorac Cardiovasc Surg. 2014;62:5-17. 18. Funkat A, Beckmann A, Lewandowski J, Frie M, Ernst M, Schiller W, Gummert JF, Cremer J. Cardiac surgery in Germany during 2013: a report on behalf of the German Society for Thoracic and Cardiovascular Surgery. Thorac Cardiovasc Surg. 2014;62: 380-92.

19. Beckmann A, Funkat AK, Lewandowski J, Frie M, Ernst M, Hekmat K, Schiller W, Gummert JF, Cremer JT. Cardiac Surgery in Germany during 2014: A Report on Behalf of the German Society for Thoracic and Cardiovascular Surgery. Thorac Cardiovasc Surg. 2015;63:258-69.

20. Beckmann A, Funkat AK, Lewandowski J, Frie M, Ernst M, Hekmat K, Schiller W, Gummert JF, Welz A. German Heart Surgery Report 2015: The Annual Updated Registry of the German Society for Thoracic and Cardiovascular Surgery. Thorac Cardiovasc Surg. 2016;64:462-74.

21. Puls M, Lubos E, Boekstegers P, von Bardeleben RS, Ouarrak T, Butter C, Zuern CS, Bekeredjian R, Sievert H, Nickenig G, Eggebrecht H, Senges J, Schillinger W. One-year outcomes and predictors of mortality after MitraClip therapy in contemporary clinical practice: results from the German transcatheter mitral valve interventions registry. Eur Heart J. 2016;37:703-12.

22. Iung $B$, Baron $G$, Butchart EG, Delahaye F, GohlkeBärwolf C, Levang OW, Tornos P, Vanoverschelde JL, Vermeer F, Boersma E, Ravaud P, Vahanian A. A prospective survey of patients with valvular heart disease in Europe: The Euro Heart Survey on Valvular Heart Disease. Eur Heart J. 2003;24:1231-43.

23. Sorajja P, Mack M, Vemulapalli S, Holmes DR Jr, Stebbins A, Kar S, Lim DS, Thourani V, McCarthy P, Kapadia S, Grayburn P, Pedersen WA, Ailawadi G. Initial Experience With Commercial Transcatheter Mitral Valve Repair in the United States. J Am Coll Cardiol. 2016;67:1129-40.

24. Garatti A, Castelvecchio S, Bandera F, Medda M, Menicanti L. Mitraclip procedure as a bridge therapy in a patient with heart failure listed for heart transplantation. Ann Thorac Surg. 2015;99:1796-9. 25. Smith CR, Leon MB, Mack MJ, Miller DC, Moses JW, Svensson LG, Tuzcu EM, Webb JG, Fontana GP, Makkar RR, Williams M, Dewey T, Kapadia S, Babaliaros V, Thourani VH, Corso P, Pichard AD, Bavaria JE, Herrmann HC, Akin JJ, Anderson WN, Wang D, Pocock SJ; PARTNER Trial Investigators. Transcatheter versus surgical aortic-valve replacement in high-risk patients. N Engl J Med. 2011;364:2187-98.

26. Reardon MJ, Van Mieghem NM, Popma JJ, Kleiman NS, Søndergaard L, Mumtaz M, Adams DH, Deeb GM, Maini B, Gada H, Chetcuti S, Gleason T, Heiser J, Lange R, Merhi W, Oh JK, Olsen PS, Piazza N, Williams M, Windecker S, Yakubov SJ, Grube E, Makkar R, Lee JS, Conte J, Vang E, Nguyen H, Chang Y, Mugglin AS, Serruys PW, Kappetein AP; SURTAVI Investigators. Surgical or Transcatheter Aortic-Valve Replacement in Intermediate-Risk Patients. N Engl J Med. 2017;376:1321-31. 


\section{Supplementary data}

Supplementary Appendix 1. Computation of DRG reimbursement amounts.

Supplementary Table 1. List of included OPS procedure codes that were included in the analysis to determine volumes in each specific year.

Supplementary Figure 1. Procedure volumes by age group. Supplementary Figure 2. Representation of MVS and TMVR procedure volumes at German national level, by age group.

Supplementary Figure 3. Estimated annual reimbursement amount of all TMVR cases, MVS, and resulting overall mitral valve reimbursement, University Heart Center Hamburg, 2008-2015.
Supplementary Figure 4. Comparison of nationwide and singlecentre growth rates of TMVR and MVS from 2008 to 2015.

Supplementary Figure 5. Percentages of TMVR procedures as part of overall mitral valve procedures in Germany and at an early adopting centre.

Supplementary Figure 6. Percentages of TMVR procedures as part of overall mitral valve procedures in Germany and at an early adopting centre stratified by age group.

The supplementary data are published online at: http://www.pcronline.com/

eurointervention/142nd_issue/177 


\section{Supplementary data}

\section{Supplementary Appendix 1. Computation of DRG reimbursement amounts}

German DRG reimbursement covers inpatient expenditure for the respective episode of care. For estimation of reimbursement at the single site, we obtained the DRG code assigned for each included case from the site's accounting department. These DRG codes are assigned based on each subject's combination of ICD-10 diagnosis codes and OPS procedure code(s), in consideration of the respective DRG grouping algorithm for each given year.

We then used these DRG codes to identify unadjusted case-weights in respective published DRG catalogues for the years 2008 to 2015. Applicable state-specific annual base rates were identified from the National Association of Statutory Health Insurance Funds (GKV Spitzenverband). In addition to the DRG reimbursement, applicable add-on device payments (“Neue Untersuchung- und Behandlungsmethoden [New examination and therapy approaches]" [NUB]), which were paid until 2012 prior to formal inclusion of TMVR into the DRG system, were considered. These were assumed to be 21,000 euros, based on an approximation of actual NUB payments. 
Supplementary Table 1. List of included OPS procedure codes that were included in the analysis to determine volumes in each specific year. Note that, over time, some changes in procedure coding nomenclature occurred, with some codes being split into two separate codes.

\begin{tabular}{|c|c|c|c|c|c|c|c|c|c|}
\hline Relevant procedure & & 2008 & 2009 & 2010 & 2011 & 2012 & 2013 & 2014 & 2015 \\
\hline $\begin{array}{l}\text { Operationen an Klappen und } \\
\text { Septen des Herzens und } \\
\text { herznaher Gefäße, Mitralklappe, } \\
\text { geschlossen }\end{array}$ & $\begin{array}{l}\text { Operation of valves and septa } \\
\text { of the heart and vessels } \\
\text { proximal to the heart, mitral } \\
\text { valve, closed }\end{array}$ & $5-350.2$ & $5-350.2$ & $5-350.2$ & $5-350.2$ & $5-350.2$ & $5-350.2$ & $5-350.2$ & $5-350.2$ \\
\hline $\begin{array}{l}\text { Operationen an Klappen und } \\
\text { Septen des Herzens und } \\
\text { herznaher Gefäße, Mitralklappe, } \\
\text { offen }\end{array}$ & $\begin{array}{l}\text { Operation of valves and septa } \\
\text { of the heart and vessels } \\
\text { proximal to the heart, mitral } \\
\text { valve, open }\end{array}$ & $5-350.3$ & $5-350.3$ & $5-350.3$ & $5-350.3$ & $5-350.3$ & $5-350.3$ & $5-350.3$ & $5-350.3$ \\
\hline $\begin{array}{l}\text { Ersatz von Herzklappen durch } \\
\text { Prothese, Mitralklappe, offen } \\
\text { chirurgisch, Allotransplantat }\end{array}$ & $\begin{array}{l}\text { Replacement of heart valves by } \\
\text { prosthesis, mitral valve, open } \\
\text { surgery, allograft }\end{array}$ & $5-351.11$ & $5-351.11$ & $5-351.11$ & $5-351.11$ & $5-351.11$ & $5-351.11$ & $5-351.11$ & $5-351.11$ \\
\hline $\begin{array}{l}\text { Ersatz von Herzklappen durch } \\
\text { Prothese, Mitralklappe, offen } \\
\text { chirurgisch, Xenotransplantat } \\
\text { (Bioprothese) }\end{array}$ & $\begin{array}{l}\text { Replacement of heart valves by } \\
\text { prosthesis, mitral valve, open } \\
\text { surgery, xenograft } \\
\text { (bioprosthesis) }\end{array}$ & $5-351.12$ & $5-351.12$ & $5-351.12$ & $5-351.12$ & $5-351.12$ & $5-351.12$ & $5-351.12$ & $5-351.12$ \\
\hline $\begin{array}{l}\text { Ersatz von Herzklappen durch } \\
\text { Prothese, Mitralklappe, offen } \\
\text { chirurgisch, Xenotransplantat } \\
\text { stentless }\end{array}$ & $\begin{array}{l}\text { Replacement of heart valves by } \\
\text { prosthesis, mitral valve, open } \\
\text { surgery, stentless xenograft }\end{array}$ & $5-351.13$ & $5-351.13$ & $5-351.13$ & $5-351.13$ & $5-351.13$ & $5-351.13$ & $5-351.13$ & $5-351.13$ \\
\hline $\begin{array}{l}\text { Ersatz von Herzklappen durch } \\
\text { Prothese, Mitralklappe, offen } \\
\text { chirurgisch, Kunstprothese }\end{array}$ & $\begin{array}{l}\text { Replacement of heart valves by } \\
\text { prosthesis, mitral valve, open } \\
\text { surgery, artificial prosthesis }\end{array}$ & $5-351.14$ & $5-351.14$ & $5-351.14$ & $5-351.14$ & $5-351.14$ & $5-351.14$ & $5-351.14$ & $5-351.14$ \\
\hline $\begin{array}{l}\text { Ersatz von Herzklappen durch } \\
\text { Prothese, Mitralklappe, offen } \\
\text { chirurgisch, sonstige }\end{array}$ & $\begin{array}{l}\text { Replacement of heart valves by } \\
\text { prosthesis, mitral valve, open } \\
\text { surgery, other }\end{array}$ & $5-351.1 x$ & $5-351.1 x$ & $5-351.1 x$ & $5-351.1 x$ & $5-351.1 x$ & $5-351.1 x$ & $5-351.1 x$ & $5-351.1 x$ \\
\hline $\begin{array}{l}\text { Ersatz von Herzklappen durch } \\
\text { Prothese, Mitralklappe, } \\
\text { thoraskopisch, Allotransplantat }\end{array}$ & $\begin{array}{l}\text { Replacement of heart valves by } \\
\text { prosthesis, mitral valve, } \\
\text { thorascopic, allograft }\end{array}$ & $5-351.21$ & $5-351.21$ & $5-351.21$ & $5-351.21$ & $5-351.21$ & $5-351.21$ & $5-351.21$ & $5-351.21$ \\
\hline
\end{tabular}




\begin{tabular}{|c|c|c|c|c|c|c|c|c|c|}
\hline $\begin{array}{l}\text { Ersatz von Herzklappen durch } \\
\text { Prothese, Mitralklappe, } \\
\text { thoraskopisch, Xenotransplantat } \\
\text { (Bioprothese) }\end{array}$ & $\begin{array}{l}\text { Replacement of heart valves by } \\
\text { prosthesis, mitral valve, } \\
\text { thorascopic, xenograft } \\
\text { (bioprosthesis) }\end{array}$ & $5-351.22$ & $5-351.22$ & $5-351.22$ & $5-351.22$ & $5-351.22$ & $5-351.22$ & $5-351.22$ & $5-351.22$ \\
\hline $\begin{array}{l}\text { Ersatz von Herzklappen durch } \\
\text { Prothese, Mitralklappe, } \\
\text { thoraskopisch, Xenotransplantat } \\
\text { stentless }\end{array}$ & $\begin{array}{l}\text { Replacement of heart valves by } \\
\text { prosthesis, mitral valve, } \\
\text { thorascopic, stentless xenograft }\end{array}$ & $5-351.23$ & $5-351.23$ & $5-351.23$ & $5-351.23$ & $5-351.23$ & $5-351.23$ & $5-351.23$ & $5-351.23$ \\
\hline $\begin{array}{l}\text { Ersatz von Herzklappen durch } \\
\text { Prothese, Mitralklappe, } \\
\text { thoraskopisch, Kunstprothese }\end{array}$ & $\begin{array}{l}\text { Replacement of heart valves by } \\
\text { prosthesis, mitral valve, } \\
\text { thorascopic, artificial prosthesis }\end{array}$ & $5-351.24$ & $5-351.24$ & $5-351.24$ & $5-351.24$ & $5-351.24$ & $5-351.24$ & $5-351.24$ & $5-351.24$ \\
\hline $\begin{array}{l}\text { Ersatz von Herzklappen durch } \\
\text { Prothese, Mitralklappe, } \\
\text { thoraskopisch, sonstige }\end{array}$ & $\begin{array}{l}\text { Replacement of heart valves by } \\
\text { prosthesis, mitral valve, } \\
\text { thorascopic, other }\end{array}$ & $5-351.2 x$ & $5-351.2 x$ & $5-351.2 x$ & $5-351.2 x$ & $5-351.2 x$ & $5-351.2 x$ & $5-351.2 x$ & $5-351.2 x$ \\
\hline $\begin{array}{l}\text { Valvuloplastik, Mitralklappe, } \\
\text { Anuloplastik }\end{array}$ & $\begin{array}{l}\text { Valvuloplasty, mitral valve, } \\
\text { annuloplasty }\end{array}$ & 5-353.1 & $5-353.1$ & 5-353.1 & 5-353.1 & 5-353.1 & 5-353.1 & 5-353.1 & 5-353.1 \\
\hline $\begin{array}{l}\text { Valvuloplastik, Mitralklappe, } \\
\text { Segelrekonstruktion }\end{array}$ & $\begin{array}{l}\text { Valvuloplasty, mitral valve, } \\
\text { leaflet repair }\end{array}$ & $5-353.2$ & $5-353.2$ & $5-353.2$ & $5-353.2$ & $5-353.2$ & $5-353.2$ & $5-353.2$ & 5-353.2 \\
\hline $\begin{array}{l}\text { Andere Operationen an } \\
\text { Herzklappen, Mitralklappe, } \\
\text { Rekonstruktion }\end{array}$ & $\begin{array}{l}\text { Other operations of heart } \\
\text { valves, mitral valve, repair }\end{array}$ & $5-354.12$ & $5-354.12$ & $5-354.12$ & $5-354.12$ & $5-354.12$ & $5-354.12$ & $5-354.12$ & $5-354.12$ \\
\hline $\begin{array}{l}\text { Andere Operationen an } \\
\text { Herzklappen, Mitralklappe, } \\
\text { Prothesenfixation }\end{array}$ & $\begin{array}{l}\text { Other operations of heart } \\
\text { valves, mitral valve, prosthesis } \\
\text { fixation }\end{array}$ & $5-354.13$ & $5-354.13$ & $5-354.13$ & $5-354.13$ & $5-354.13$ & $5-354.13$ & $5-354.13$ & $5-354.13$ \\
\hline $\begin{array}{l}\text { Andere Oprationen an } \\
\text { Herzklappen, Mitralklappe, } \\
\text { sonstige }\end{array}$ & $\begin{array}{l}\text { Other operations of heart } \\
\text { valves, mitral valve, other }\end{array}$ & $5-354.1 x$ & $5-354.1 x$ & $5-354.1 x$ & $5-354.1 x$ & $5-354.1 x$ & $5-354.1 x$ & $5-354.1 x$ & $5-354.1 x$ \\
\hline $\begin{array}{l}\text { Minimalinvasive Operationen an } \\
\text { Herzklappen, Endovaskuläre } \\
\text { Mitralklappenanuloplastik }\end{array}$ & $\begin{array}{l}\text { Minimally invasive operations } \\
\text { of heart valves, endovascular } \\
\text { mitral valve annuloplasty }\end{array}$ & 5-35a.2 & 5-35a.2 & 5-35a.2 & 5-35a.2 & 5-35a.2 & 5-35a.2 & 5-35a.2 & 5-35a.2 \\
\hline $\begin{array}{l}\text { Minimalinvasive Operationen an } \\
\text { Herzklappen, Endovaskuläre } \\
\text { Implantation eines } \\
\text { Mitralklappenersatzes }\end{array}$ & $\begin{array}{l}\text { Minimally invasive operations } \\
\text { of heart valves, endovascular } \\
\text { mitral valve replacement }\end{array}$ & $n / a$ & 5-35a.3 & 5-35a.3 & Split & Split & Split & Split & Split \\
\hline $\begin{array}{l}\text { Minimalinvasive Operationen an } \\
\text { Herzklappen, Implantation eines } \\
\text { Mitralklappenersatzes, } \\
\text { endovaskulär }\end{array}$ & $\begin{array}{l}\text { Minimally invasive operations } \\
\text { of heart valves, implantation of } \\
\text { mitral valve replacement, } \\
\text { endovascular }\end{array}$ & $\mathrm{n} / \mathrm{a}$ & $\mathrm{n} / \mathrm{a}$ & $\mathrm{n} / \mathrm{a}$ & 5-35a.30 & 5-35a.30 & 5-35a.30 & 5-35a.30 & 5-35a.30 \\
\hline
\end{tabular}




\begin{tabular}{|c|c|c|c|c|c|c|c|c|c|}
\hline $\begin{array}{l}\text { Minimalinvasive Operationen an } \\
\text { Herzklappen, Implantation eines } \\
\text { Mitralklappenersatzes, } \\
\text { transapikal, ab 2015: ohne } \\
\text { perkutan apikales Zugangs- und } \\
\text { Verschlusssystem }\end{array}$ & $\begin{array}{l}\text { Minimally invasive operations } \\
\text { of heart valves, implantation of } \\
\text { mitral valve replacement, } \\
\text { transapical, since 2015: without } \\
\text { percutaneous apical access and } \\
\text { closure system }\end{array}$ & $\mathrm{n} / \mathrm{a}$ & $\mathrm{n} / \mathrm{a}$ & $\mathrm{n} / \mathrm{a}$ & 5-35a.31 & 5-35a.31 & 5-35a.31 & 5-35a.31 & 5-35a.31 \\
\hline $\begin{array}{l}\text { Minimalinvasive Operationen an } \\
\text { Herzklappen, Implantation eines } \\
\text { Mitralklappenersatzes, } \\
\text { transapikal, ab 2015: mit } \\
\text { perkutan apikales Zugangs- und } \\
\text { Verschlusssystem }\end{array}$ & $\begin{array}{l}\text { Minimally invasive operations } \\
\text { of heart valves, implantation of } \\
\text { mitral valve replacement, } \\
\text { transapical, since 2015: with } \\
\text { percutaneous apical access and } \\
\text { closure system }\end{array}$ & & $\mathrm{n} / \mathrm{a}$ & $\mathrm{n} / \mathrm{a}$ & $\mathrm{n} / \mathrm{a}$ & $\mathrm{n} / \mathrm{a}$ & $\mathrm{n} / \mathrm{a}$ & $n / a$ & 5-35a.32 \\
\hline $\begin{array}{l}\text { Minimalinvasive Operationen an } \\
\text { Herzklappen, Endovaskuläre } \\
\text { ventrikuläre } \\
\text { Mitralklappenrekonstruktion }\end{array}$ & $\begin{array}{l}\text { Minimally invasive operations } \\
\text { of heart valves, endovascular } \\
\text { ventricular mitral valve repair }\end{array}$ & $\mathrm{n} / \mathrm{a}$ & $\mathrm{n} / \mathrm{a}$ & 5-35a.4 & Split & Split & Split & Split & Split \\
\hline $\begin{array}{l}\text { Minimalinvasive Operationen an } \\
\text { Herzklappen, endovaskuläre } \\
\text { Mitralklappenrekonstruktion, } \\
\text { transarteriell }\end{array}$ & $\begin{array}{l}\text { Minimally invasive operations } \\
\text { of heart valves, endovascular } \\
\text { mitral valve repair, transarterial }\end{array}$ & $\mathrm{n} / \mathrm{a}$ & $\mathrm{n} / \mathrm{a}$ & $\mathrm{n} / \mathrm{a}$ & $5-35 a .40$ & 5-35a.40 & 5-35a.40 & 5-35a.40 & $5-35 a .40$ \\
\hline $\begin{array}{l}\text { Minimalinvasive Operationen an } \\
\text { Herzklappen, sonstige }\end{array}$ & $\begin{array}{l}\text { Minimally invasive operations } \\
\text { of heart valves, other }\end{array}$ & 5-35a.x & 5-35a.x & 5-35a.x & 5-35a.x & 5-35a.x & 5-35a.x & 5-35a.x & 5-35a.x \\
\hline $\begin{array}{l}\text { Minimalinvasive Operationen an } \\
\text { Herzklappen, N.n.bez. }\end{array}$ & $\begin{array}{l}\text { Minimally invasive operations } \\
\text { of heart valves, not specified }\end{array}$ & 5-35a.y & 5-35а.у & 5-35a.y & 5-35a.y & 5-35a.y & 5-35a.y & 5-35a.y & 5-35a.y \\
\hline $\begin{array}{l}\text { Minimalinvasive Operationen an } \\
\text { Herzklappen, endovaskuläre } \\
\text { Mitralklappenrekonstruktion, } \\
\text { transvenös }\end{array}$ & $\begin{array}{l}\text { Minimally invasive operations } \\
\text { of heart valves, endovascular } \\
\text { mitral valve repair, transvenous }\end{array}$ & $\mathrm{n} / \mathrm{a}$ & $\mathrm{n} / \mathrm{a}$ & $\mathrm{n} / \mathrm{a}$ & 5-35a.41 & 5-35a.41 & 5-35a.41 & 5-35a.41 & 5-35a.41 \\
\hline $\begin{array}{l}\text { Perkutan-transluminale } \\
\text { Gefäßintervention an Herz- und } \\
\text { Koronargefäßen, } \\
\text { Ballonvalvuloplastie, Mitralklappe }\end{array}$ & $\begin{array}{l}\text { Percutaneous-transluminal } \\
\text { interventions of vessels related } \\
\text { to heart and coronary vessels, } \\
\text { balloon valvuloplasty, mitral } \\
\text { valve }\end{array}$ & 8-837.a1 & 8-837.a1 & 8-837.a1 & 8-837.a1 & 8-837.a1 & 8-837.a1 & 8-837.a1 & 8-837.a1 \\
\hline
\end{tabular}


Supplementary Figure 1. TMVR procedures (left) and MVS procedures (right) by age group at our centre for the period 2008-2015, EAC (top) and German national level (bottom).

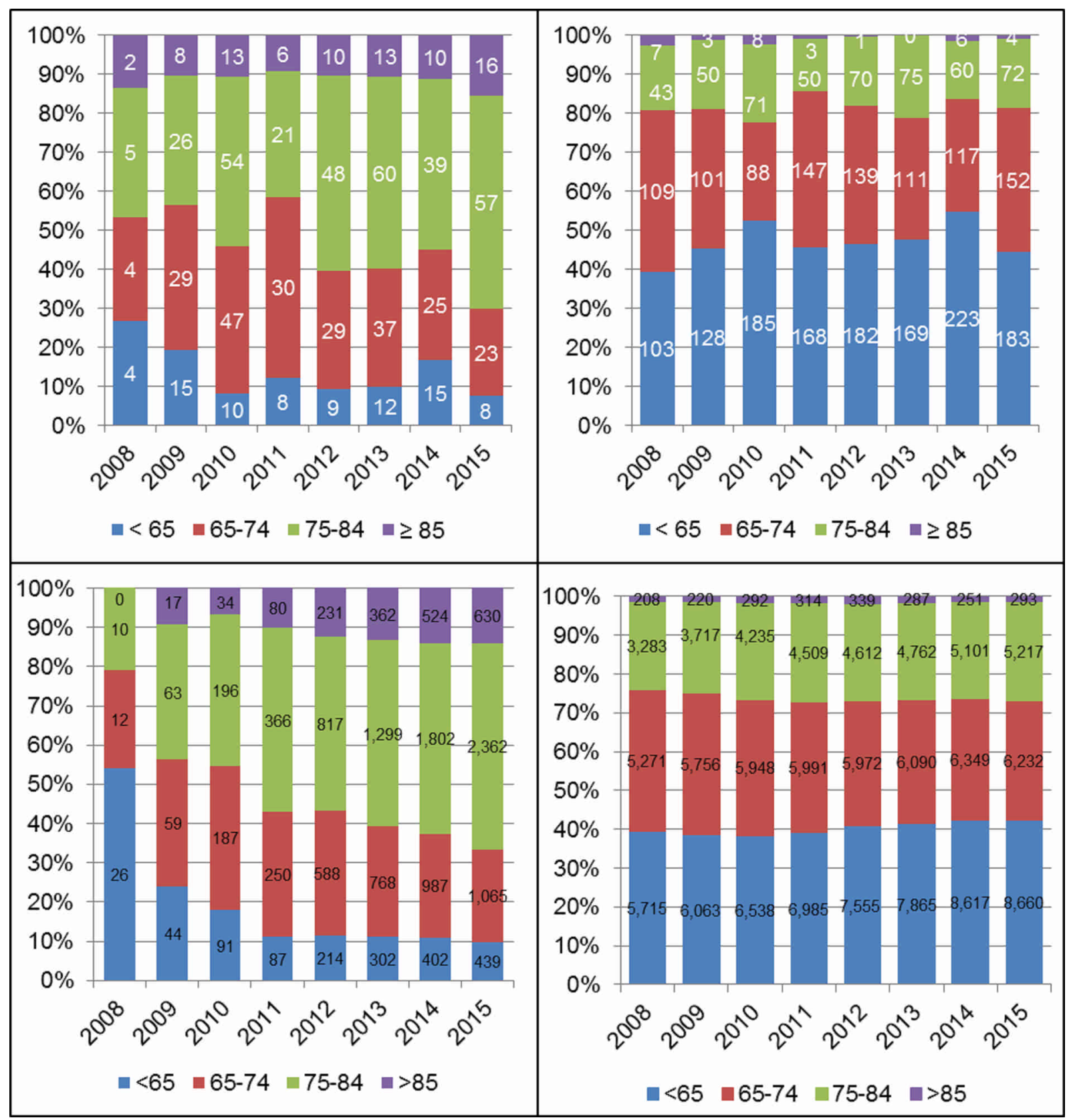


Supplementary Figure 2. Representation of MVS and TMVR procedure volumes at German national level, by age group. A) $<65$ years old; B) $65-74$ years old; C) $75-84$ years old; D) $>85$ years old.

A)

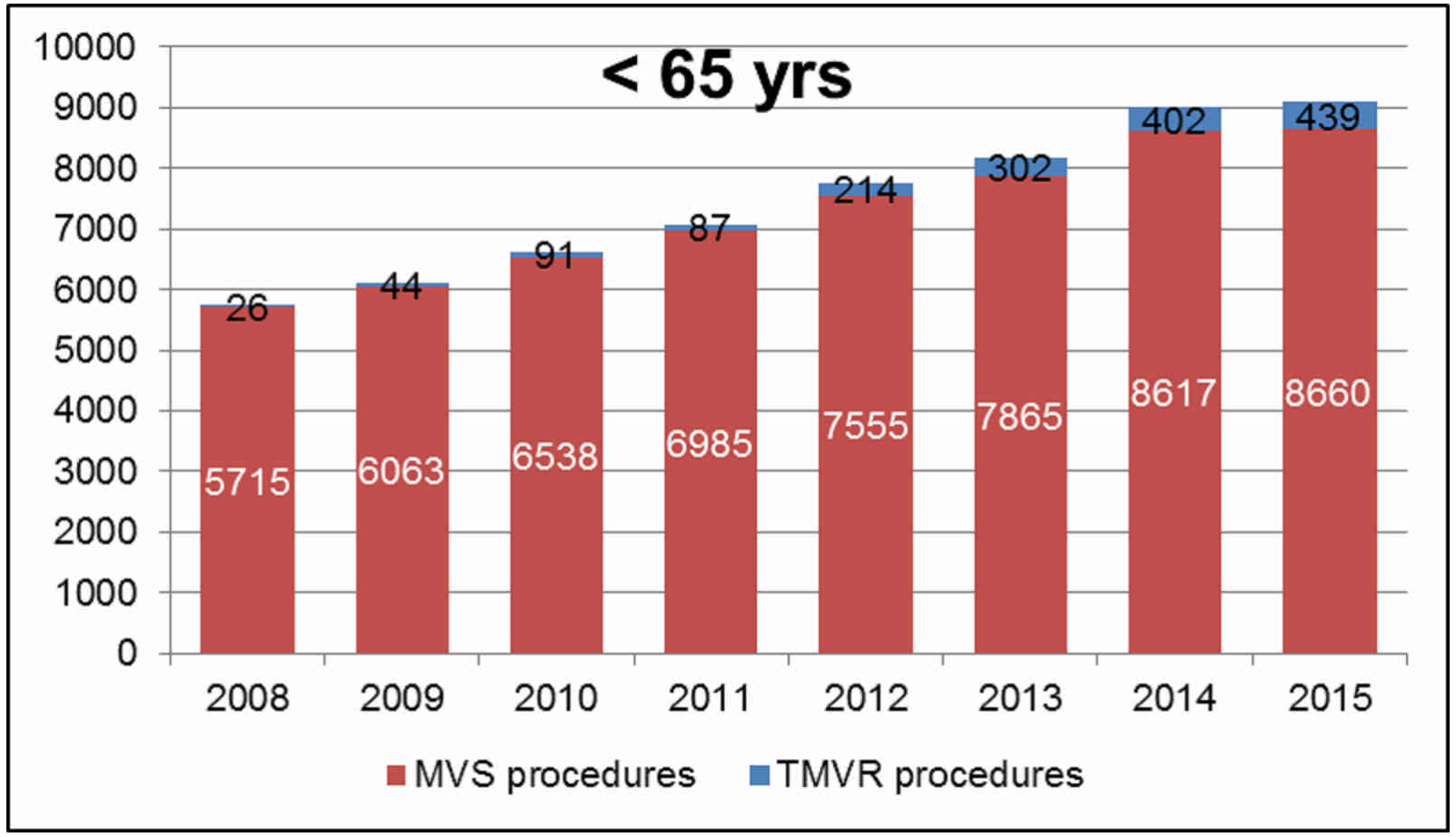

B.

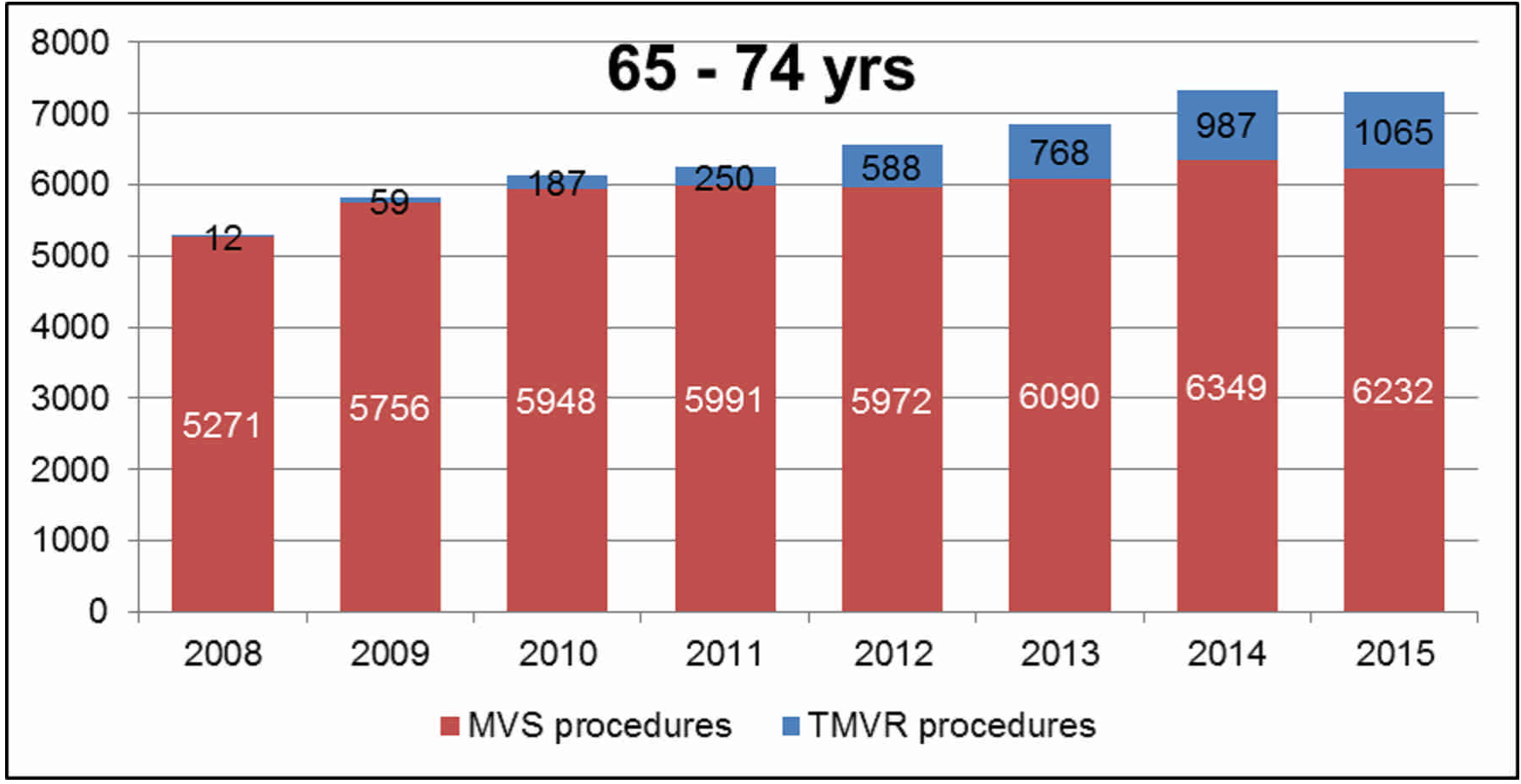


c.

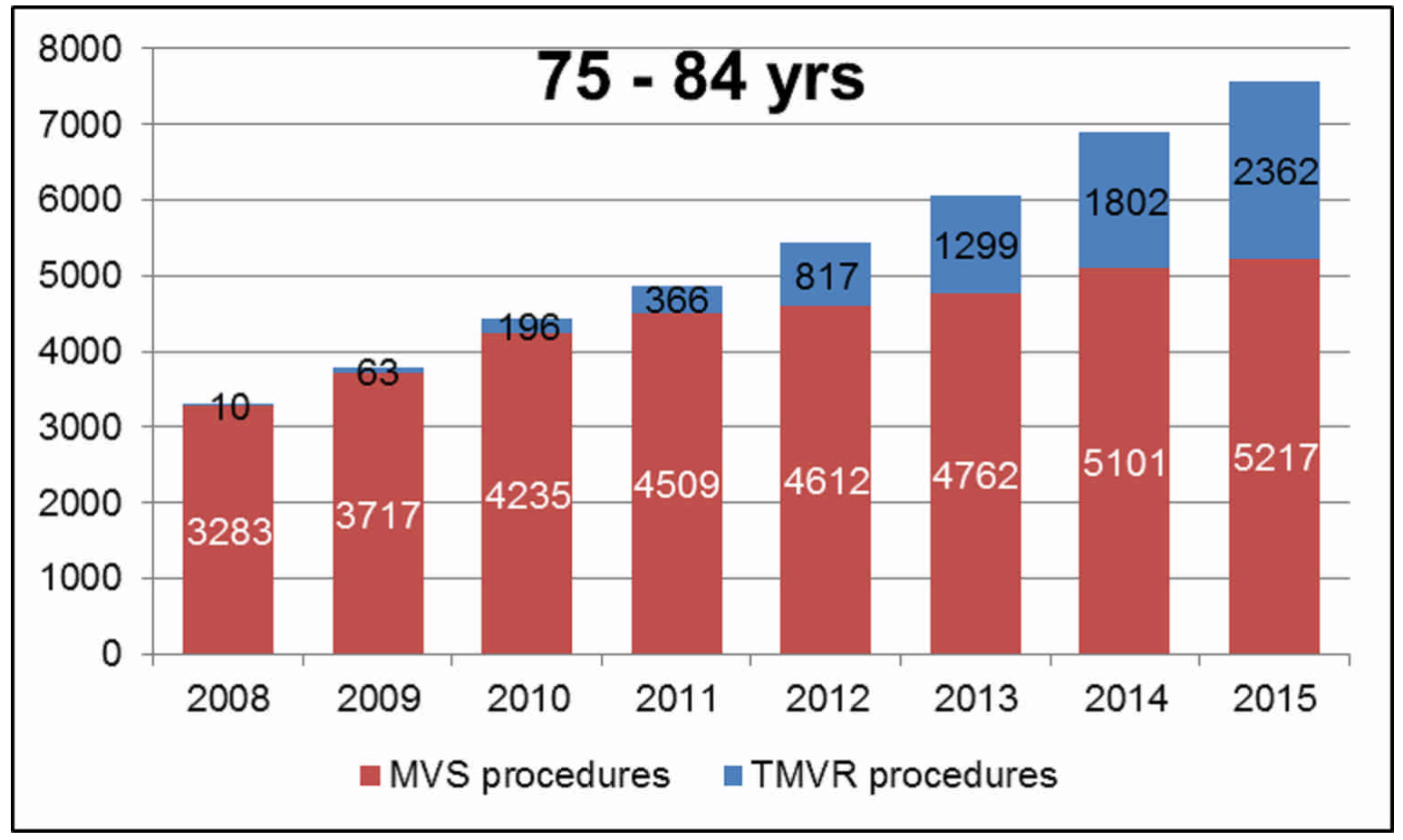

D.

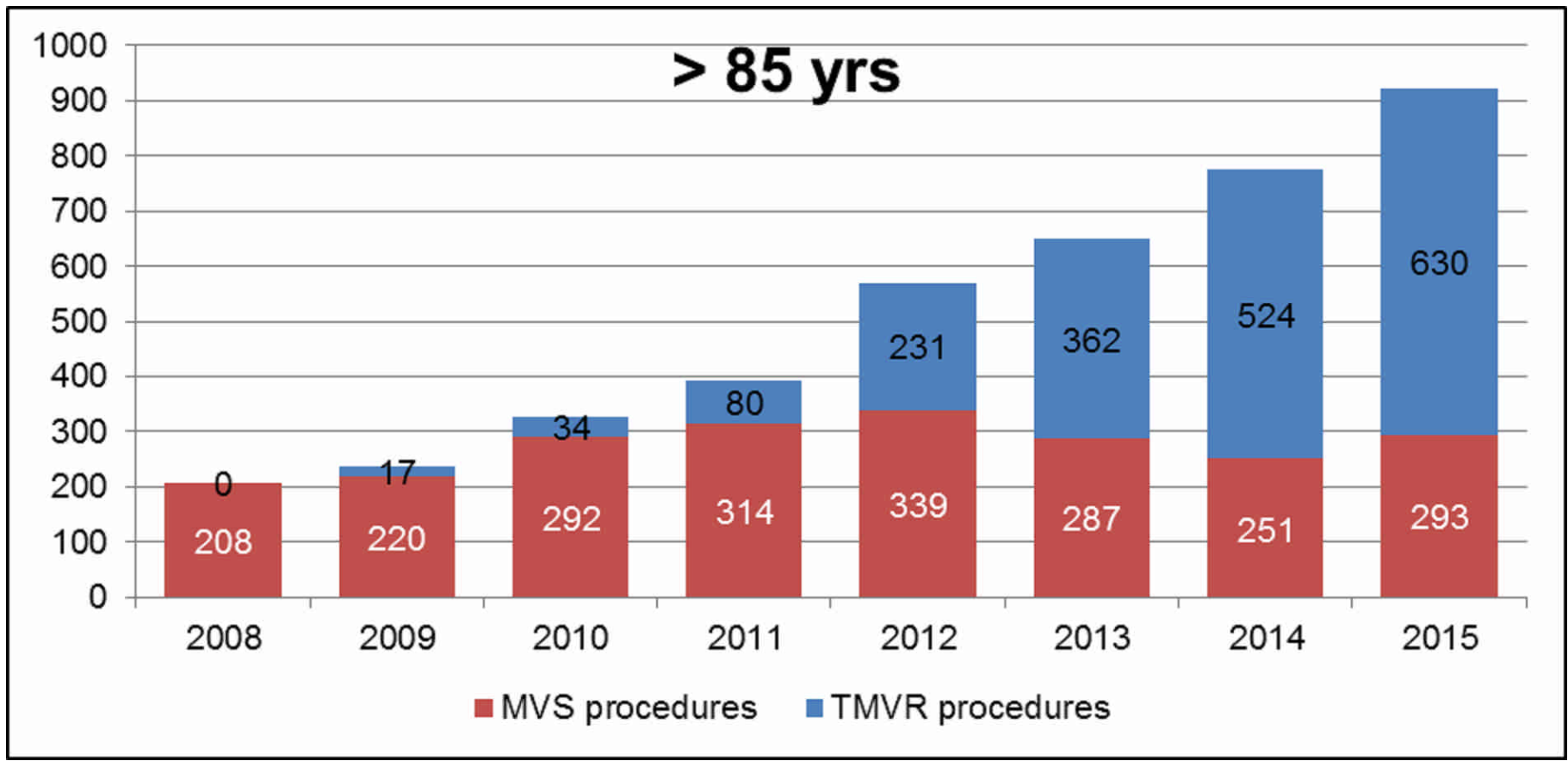


Supplementary Figure 3. Estimated annual reimbursement amount of all TMVR cases, MVS, and resulting overall mitral valve reimbursement, University Heart Center Hamburg, 2008-2015.*

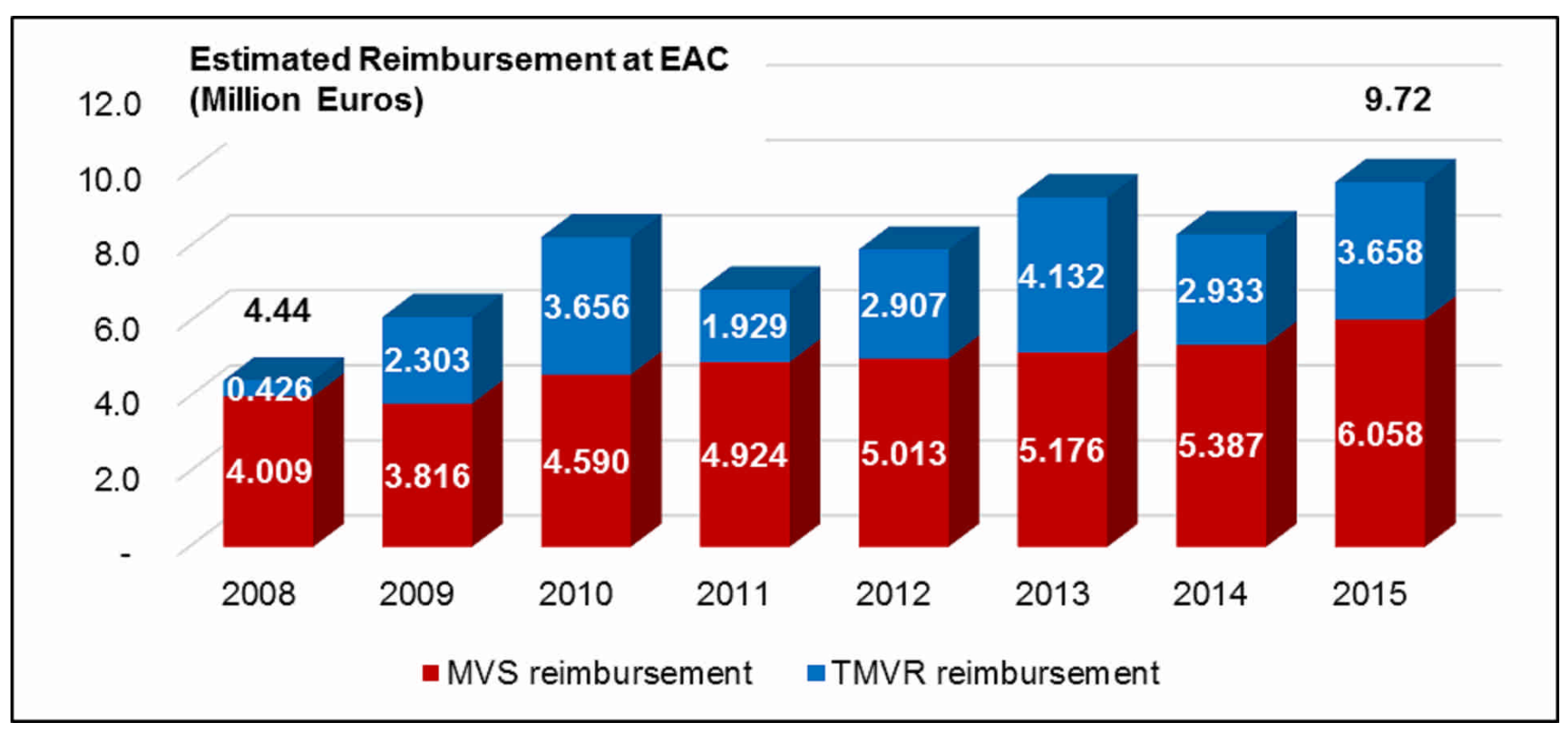

*Per-case reimbursement for TMVR increased from 28,400 euros in 2008 to 35,500 euros in 2015 $(+25 \%)$. 
Supplementary Figure 4. Comparison of nationwide and single-centre growth rates of TMVR and MVS from 2008 to 2015.

A. TMVR and MVS growth rates from 2008 to 2015 in Germany

B. TMVR and MVS growth rates from 2008 to 2015 at an early adopting centre

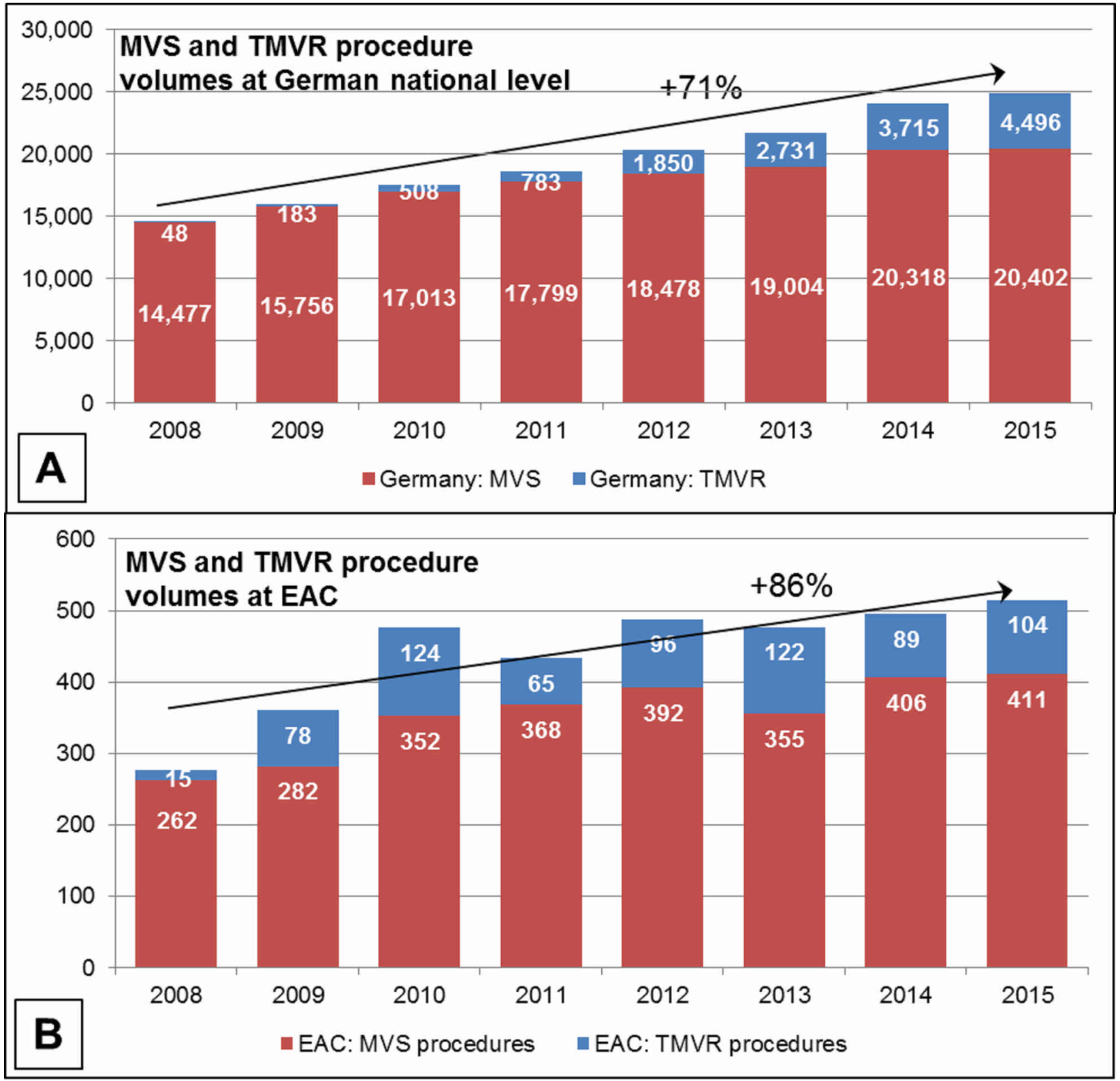


Supplementary Figure 5. Percentages of TMVR procedures as part of overall mitral valve procedures in Germany and at an early adopting centre.




Supplementary Figure 6. Percentages of TMVR procedures as part of overall mitral valve procedures in Germany and at an early adopting centre stratified by age group.

A. Age stratified TMVR percentages at an early adopting centre from 2008 to 2015

B. Age stratified TMVR percentages in Germany from 2008 to 2015

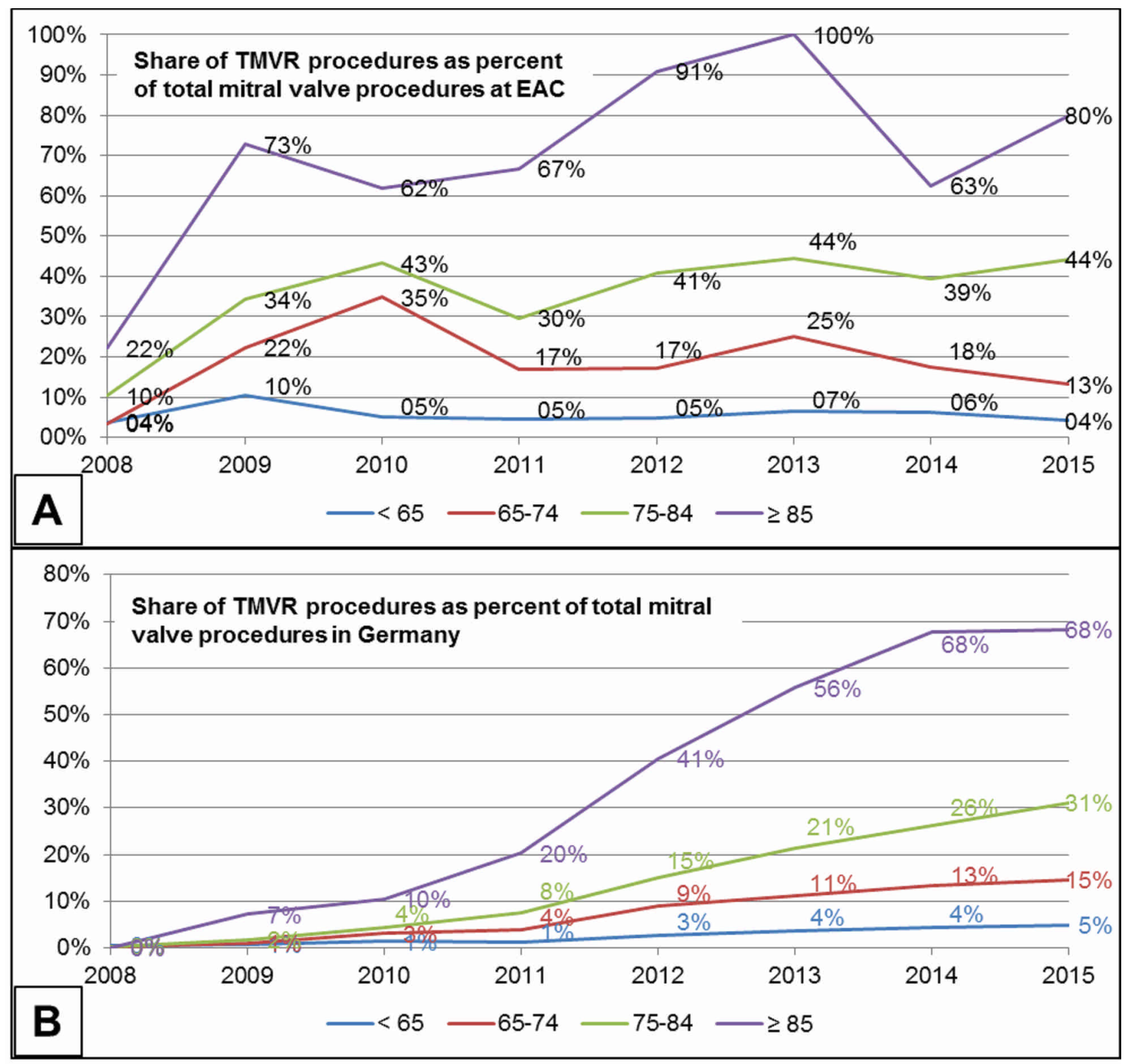

